Review

\title{
Cell junctions in the prostate: an overview about the effects of Endocrine Disrupting Chemicals (EDCS) in different experimental models
}

\author{
Wellerson R. Scarano ${ }^{\mathrm{a}, *}$, Cristiane F. Pinho ${ }^{\mathrm{a}}$, Lorenzo Pissinatti ${ }^{\mathrm{b}}$, Bianca F. Gonçalves ${ }^{\mathrm{a}}$, \\ Leonardo O. Mendes ${ }^{\mathrm{c}}$, Silvana G.P. Campos ${ }^{\mathrm{d}}$ \\ ${ }^{a}$ Institute of Biosciences, São Paulo State University (UNESP), Botucatu, SP, Brazil \\ ${ }^{\mathrm{b}}$ Department of Veterinary Pathology, Universidade de Sorocaba (UNISO), Sorocaba, SP, Brazil \\ ${ }^{\mathrm{c}}$ Universidade do Oeste Paulista (UNOESTE), Presidente Prudente, SP, Brazil \\ ${ }^{\mathrm{d}}$ Institute of Biosciences, Letters and Exact Sciences, São Paulo State University (UNESP), São José do Rio Preto, SP, Brazil
}

\section{A R T I C L E I N F O}

\section{Keywords:}

EDCs (Endocrine Disrupting Chemicals) Cell junctions

EMT (epithelial-mesenchymal transition) Toxicants

\begin{abstract}
A B S T R A C T
Throughout the last decades, increasing exposure to environmental Endocrine Disruptors Chemicals (EDCs) has been associated with the occurrence of male reproductive disorders, such as impairment of prostate development and function, increase of susceptibility to oncogenesis, Epithelial-Mesenchymal Transition and the metastatic invasive potential. Nevertheless, few studies address the mechanisms involved in these alterations, especially those related to cell junctions, which are hormonally regulated and, therefore, possible EDCs targets. The cellular mechanisms discussed in this review are addressed to EDCs actions on tight, gap and adherent junctions and its related genes and proteins, such as claudin- $1,-3,-4$ and -8 , connexin- 32 and -43 , E-cadherin and $\beta$-catenin, respectively. The impairment of cell junction function, mainly due EDCs exposure during the prostate's critical window of development, can corroborate to acquire a mesenchymal phenotype by epithelial cells and the prostate microenvironment becomes susceptible to development of lesions in the latter stages of life.
\end{abstract}

\section{Introduction}

Over last few decades, increasing exposure to environmental xenobiotics has been associated with the occurrence of male reproductive disorders. In this context, some environmental toxicants and pharmaceutical compounds can disrupt prostate development with antiandrogenic and estrogenic activity, such as phthalates, bisphenol A (BPA), diethylstilbestrol (DES), vinclozolin and flutamide, among others [1-6]. These chemicals have the ability to enter cells, bind to androgen or estrogen receptors, and disrupt androgen and estrogenmediated signaling, compromising the mounting and operation of hormone-dependent cellular junctions [7]. To cope with such concerns, the protection of human health and of the environment from Endocrine Disrupting Chemicals (EDCs) and chemical carcinogens has become a high priority for regulatory authorities, which are considering a large variety of approaches [8].

Knowledge regarding the complex development of the organs of male genital system as well as the nature of their interactions with EDCs has increased substantially [9]. Recent work by our group and others has shown that exposure to plasticizers may alter prostate development, increasing the susceptibility of this organ to carcinogenesis $[2,5,10]$. Additionally, prostate development and function are dependent on the interactions between the epithelium and the mesenchyma/stroma, in addition to the interactions between the different cell types in the epithelium. The loss of adhesion between prostatic epithelial cells has been extensively studied during the Epithelial-Mesenchymal Transition (EMT), a highly specialized process associated with oncogenesis and tumor metastasis $[3,11,12]$. Tumor cells undergo the EMT to promote invasion, migration and subsequent metastasis. During these processes, epithelial cells repress genes encoding cell adhesion proteins (such as Ecadherin) and modify the type of intermediate filaments expressed. EMT is accompanied by acquisition of mesenchymal characteristics that include vimentin, $\mathrm{N}$-cadherin and osteopontin expression, the synthesis of extracellular matrix molecules (such as fibronectin and certain types of collagen) and acquisition of a flattened phenotype which becomes more migratory. Following EMT, the cells may differentiate into other cell types or revert back to epithelial cells [13-15]. However, in relation to the processes triggered by EDCs and other toxicants in non-tumor prostatic tissue, there are few studies that relate their effects to adhesion molecules in cell-cell and cell-extracellular matrix interactions.

\footnotetext{
* Corresponding author at: Departamento de Morfologia (Department of Morphology), Instituto de Biociências - UNESP - Institute of Biosciences, Botucatu, SP, CEP 18618-970, Brazil.

E-mail address: wellerson.scarano@unesp.br (W.R. Scarano).
} 
Thus, this revision was intended to compile the main discussions on this topic in recent years.

\section{Prostatic Morphogenesis and molecules involved in cell junctions}

The prostate develops from the pelvic part of the Urogenital Sinus (UGS), located at the base of the developing urinary bladder. The secretion of testosterone by the fetal testicles initiates prostate morphogenesis, thus prostatic buds (solid epithelial projections) emerge and extend towards the surrounding mesenchyma of the UGS, due to a coordinated action between cell proliferation, adhesion and migration [16-18].

In rodents, the buds' ramification begins in the neonatal period, as does ductal canalization (lumen formation) and epithelial and stromal cytodifferentiation. The bifurcation in primary, secondary and tertiary lateral branches leads to the formation of a mature ductal network divided into three different prostatic lobes: ventral, dorsolateral and anterior $[18,19]$. In humans, although similar morphogenetic events occur, the process leads to the formation of a single organ, with three distinct zones: central, peripheral and transitional. The definitive prostatic architecture is established by puberty, when the prostate acquires its secretory function [19]. The morphological processes present during prostate morphogenesis in rodents and humans are shown in Fig. 1.

Besides the classical hormonal dependence of steroid hormones, the prostatic development, as well as the maintenance of adult prostatic tissue homeostasis, is also dependent on cell-cell interactions through a paracrine signaling between epithelium and mesenchyme [16,20-22]. These interactions are mainly mediated by different types of cell junctions, highlighting the tight, anchoring and gap junctions that guide the epithelial cells' proliferation and prostate bud' growth $[9,15]$.

Tight junctions are junctional complexes formed by integrated transmembrane proteins such as occludins and claudins that create a continuous intercellular barrier between epithelial cells, maintaining cellular polarity and controlling the passage of molecules through the epithelium [7,23]. Some claudins (claudin-3, -4, -5, -8 -10) are located between the prostate luminal epithelial cells while others (claudin-1 and -7) confer cellular adhesion and signaling to the extracellular matrix $[7,24]$.

Another important type of cell junction is anchoring junctions, which maintain tissue integrity through the attachment of cytoskeletal proteins from adjacent cells by desmosomes and adherent junctions composed of cadherins ( $\mathrm{N}, \mathrm{E}$-cadherin) and catenins ( $\alpha, \beta$-catenin) proteins -, as well as through the connection between cellular proteins and extracellular matrix proteins by hemidesmosomes [7].

E-cadherin correlates with cell adhesion, migration and intracellular signaling dynamics during epithelial development [25]. Although Ecadherin is specifically required for embryogenesis, it also has great importance in maintaining epithelial homeostasis and its negative regulation is associated with an invasive phenotype in prostate cancer [25]. While E-cadherin is primarily expressed in epithelial cells, Ncadherin is present in several cell types, including mesenchymal cells. An increase in N-cadherin expression, associated with loss of E-cadherin expression, is observed during the EMT as well as in prostate cancer $[7,26]$.

Gap junctions, a third type of cell junction, mediate the direct communication between adjacent cells by intercellular pores constituted by connexin proteins (Cxs), which allow for the passage of small molecules $(<1 \mathrm{kDa})$, ensuring the synchronization of cellular behavior and tissue homeostasis, which are important during the development and adult period $[7,27,28]$. In addition to the well-defined function in the gap junctions intercellular communication, as reviewed by Boucher et al. [29], Cxs are also important in extracellular communication (hemichannels) and intracellular signaling (scaffold proteins). The most important connexins are $\mathrm{Cx}-43$ and -32 , differentially regulated during the prostatic morphogenesis. Throughout prostatic differentiation, Cx-43 expression in undifferentiated epithelial and mesenchymal cells decreases to give rise to increased expression of $\mathrm{Cx}$ 32. Finally, in the adult prostate, the expression of $\mathrm{Cx}-32$ occurs in secretory epithelial cells and $\mathrm{Cx}-43$ is restricted to basal cells [30]. Studies suggest that the loss of $\mathrm{Cx}-43$ is an important event in the development of prostate cancer, being correlated with the loss of tissue architecture and synchronized action between prostatic compartments, leading to increasingly invasive potential of prostate cancer cells and their extravasation [31].

Due to the importance of cellular junctions and adhesion molecules involved in the context of prostatic morphogenesis and homeostasis of adult tissue, attention now turns to environmentally toxic substances, with potential deregulatory action on these molecules. Focusing on mechanisms by which chemicals disrupt cellular interactions is

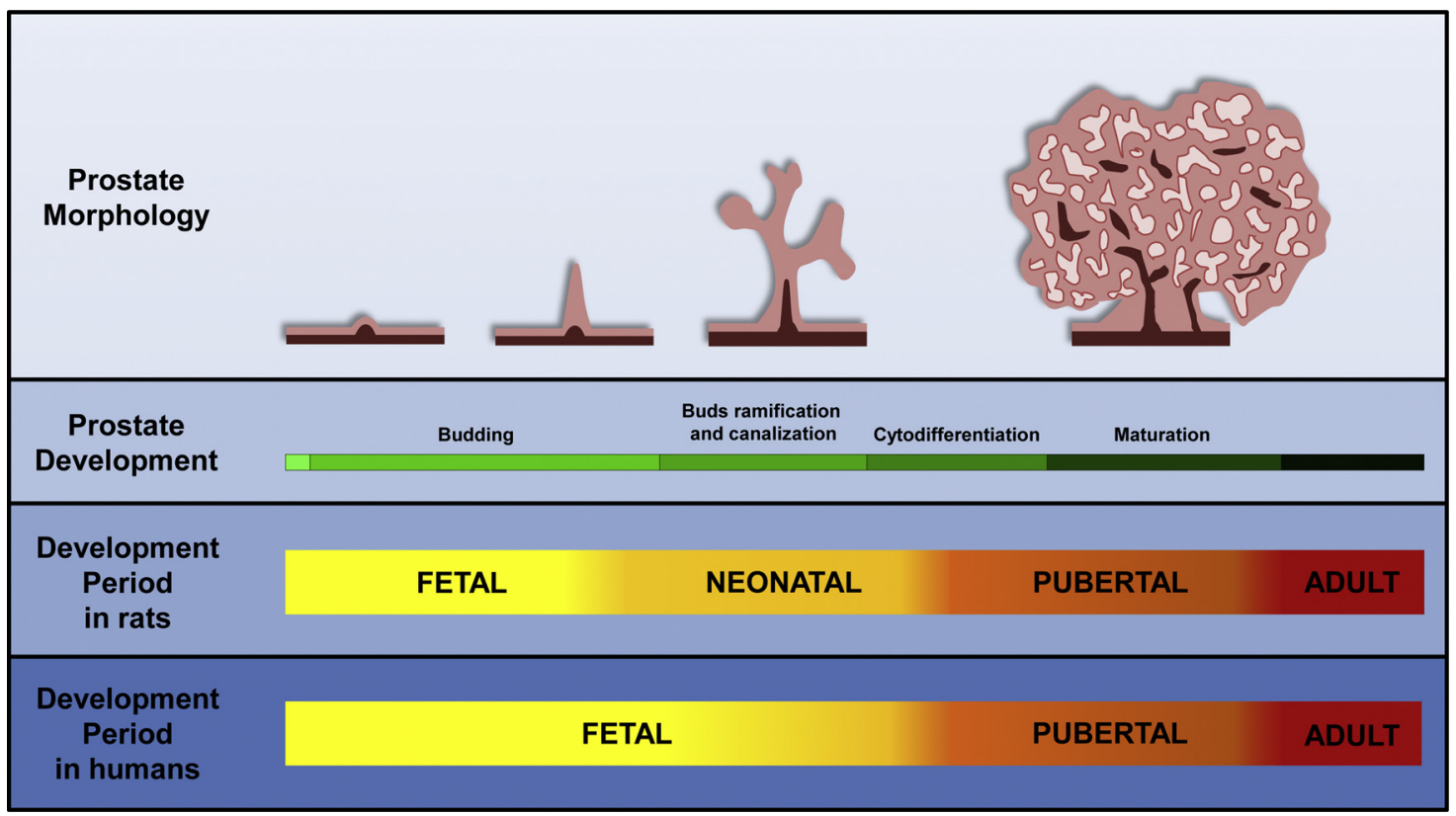

Fig. 1. Prostate morphogenesis: developmental stages, timeline and comparison between rats and humans (Adapted from Prins and Putz [99]). 
essential for understanding structural and functional abnormalities on the prostate, as well as the initiation of various diseases in this organ.

\section{Xenobiotics acting in cell junctions impairing prostatic development}

Studies with animals and prostatic cell lines models showed androgenic involvement in the regulation of some tight junctions proteins, such as claudin-4, -7 and -8 [32,33], adherent junctions, such as Ecadherin and $\beta$-catenin [34], and gap junctions, such as Cx-43 [35].

Neonatal administration of the antiandrogenic flutamide $(50 \mathrm{mg} /$ $\mathrm{kg}$ ) during the period of prostatic development in pigs decreased Ecadherin gene expression and increased $\beta$-catenin that persisted into adulthood [36]. In addition, Gorowska et al. [36] observed a delocalization of the $\beta$-catenin membrane protein into the cells cytoplasm in the perinuclear region after treatment with flutamide. This change in $\beta$ catenin's location would result from the accumulation of this protein and its functional deficiency caused by an insufficient level of testosterone. Other studies with flutamide showed a reduction in the prostatic acini size, inflammatory alterations and an increase of the $\mathrm{Cx}-43$ gene and protein expression in adulthood after fetal and neonatal exposure that would be a reflection of altered differentiation of the prostatic epithelium due to androgenic signaling disrupting [37].

Tributyltin (TBT) is an organotin used as an antifouling agent in paint for boats, in wood preservatives and as a disinfectant in water cooling systems [38]. In a study with pregnant rats, Barthelemy et al. [23] observed a significant dose-dependent decrease in E-cadherin mRNA levels in the ventral prostate of adult rats exposed in utero to increasing doses of TBT $(2.5,10$, and $20 \mathrm{mg} / \mathrm{kg})$. G-proteins play an essential role in the signaling process, implicating cell adhesion molecules such as cadherins [23]. Microarray analyses indicated that four Gproteins, Rab16, Rab 14, RaI A and GNAI2, significantly decreased in the TBT-treated rats, indicating a possible imbalance in the process related to establishment and/or maintenance of cell polarity. In this study, E-cadherin and claudin-1 expression levels decreased in a dosedependent response, while claudin- 3 and -8 increased in high-dose treatments, suggesting that some compensatory effect among the various claudins present in the ventral prostate. In addition, claudin-1 immunolocalization was shown to be spread throughout the plasma membrane in animals exposed to TBT, rather than restricted to the apical margin of adjacent epithelial cells, as in the control group, suggesting possible changes in the tight junctions function [23].

Exposure to estrogens, such as $17 \beta$-estradiol, and xenoestrogenic compounds, including diethylstilbestrol and bisphenol A, during the neonatal period is capable of delaying prostate growth, epithelial branching and differentiation, in addition to permanently altering prostatic secretory function and androgens response during adulthood $[1,39,40]$. These effects may be due to impairment of cell-cell communication associated with a higher incidence of prostatic hyperplasia and neoplasia in aging [30,39,41]. Habermann et al. [30] demonstrated that neonatal estrogenzation led to redistribution in Cx-32 localization from the membrane to the cytoplasm of epithelial cells in the ventral prostate of young rats, similar to events associated with prostatic carcinogenesis [42]. In addition, in estrogenized aged animals, there was a decrease in prostatic expression of Cx-32 and E-cadherin, and increased expression of $\mathrm{Cx}-43$, indicating aberrant cell junctions and tissue dedifferentiation [30].

Exposure of primary mesenchymal cells from fetal rat prostate to low (10 pM and $100 \mathrm{pM})$ and high $(100 \mathrm{nM})$ doses of $17 \beta$-estradiol revealed compromising of genes involved in steroid hormones signaling pathways (androgen receptor, estrogen receptor $\alpha$ ), cytokines, cytoskeleton reorganization (actins) and cell communication and adhesion (claudins, cadherins, $\mathrm{Cx}-43, \mathrm{TGF}-\beta$ and Wnt/ $\beta$-catenin pathways) [43]. Taylor et al. suggest these effects could interfere permanently with prostate morphogenesis and growth process, which would lead to reduced prostate size and hormone responsiveness in adulthood [43].
BPA, a widely used chemical for manufacturing plastic products and epoxy resins [44], has been found in human serum, with warranted attention to higher concentrations in placental and fetal tissues [45]. Ramos et al. [46] suggested that in utero exposure to low doses of BPA $(25-250 \mu \mathrm{g} / \mathrm{Kg} /$ day) in rats altered the differentiation pattern of periductal stromal cells of the ventral prostate. Additionally, environmentally relevant doses of BPA during the neonatal developmental period in rats increases susceptibility to precancerous prostatic lesions in aged animals and sensitizes the prostate gland to adult induced hormonal carcinogenesis [44].

In addition to the signaling triggered by androgenic and estrogenic receptors, it is known that Aryl Hydrocarbon Receptor (AHR) can also compromise prostate growth and branching. This is because AHR can bind to a wide variety of environmental chemical contaminants, especially 2,3,7,8-tetrachlorodibenzo-p-dioxin (TCDD), inhibiting the formation of prostatic buds and causing organ agenesis [47]. Schneider et al. [48] described that intrauterine TCDD administration $(5 \mathrm{~mL} / \mathrm{kg})$ in rats activated the AHR in mesenchyme cells of urogenital sinus, interrupting the paracrine signaling towards the prostate epithelium, probably due to $\mathrm{Wnt} / \beta$-catenin signaling pathway disruption.

\section{Prostate inflammation induced by EDCs and cell adhesion}

In recent years, studies have raised questions about the etiology and the consequences arising from the inflammatory process. In the prostate microenvironment, the inflammatory process is the subject of discussion due to its unclear role in the tumorigenesis, providing chemokines, interleukins, growth factors and reactive oxygen species that destabilize normal prostate homeostasis and increase the risk of prostate cancer [49].

Yatkin et al. [50] proposed the estradiol (E2)/testosterone (T) imbalance as a crucial factor for the prostatic inflammation development. E2 administration $(0.07 \mathrm{mg} /$ day, 21 days) with low doses of dihydrotestosterone (DHT, $0.14 \mathrm{mg} /$ day, 21 days) and $\mathrm{T}(0.24 \mathrm{mg} /$ day, 21 days) in castrated Noble rats was responsible for the increase of stromal, perivascular and glandular inflammatory infiltrates. These inflammatory foci were absent with the higher doses of androgens $(0.7 \mathrm{mg} /$ day of DHT; $2.4 \mathrm{mg} /$ day of T). The inflammatory process destabilized the glandular histoarchitecture, with CD8 + T lymphocytes between epithelial cells and luminal neutrophils and macrophage. E2/T imbalance is one of the consequences of endocrine disruptors, by the interference with the sex hormones binding and action, as was well established by Kavlock et al. [51]. There are several chemical compounds that are able to mimic the estrogenic action, activating or inhibiting estrogen receptors [52], and will consequently trigger the inflammatory process [4].

The prostatic inflammation caused by the hormonal environmental imbalance can affect the tight junction in the prostatic epithelium, specifically claudins. Meng et al. [32] observed a reduction in claudin-4 and -8 genes expression after castration, being negatively correlated with the number of intraepithelial macrophages and lymphocytes, showing the significant role of testosterone in the cellular junctions regulation.

The gap junctions proteins, such as $\mathrm{Cx}-32$ and -43 , are also hormonally regulated. Neonatally estrogenized Sprague-Dawley rats (estradiol benzoate, $1 \mathrm{mg} / \mathrm{ml}$ ) on days 1,3 and 5 postnatal showed, at 90 days old, a reduction in the proportion of Cx-32 expressing cells and an increase in Cx-43 expressing cells in areas with epithelial dysplasia and inflammatory infiltrates of ventral prostate $[30,53]$. This shift in the connexin expression pattern reflects the increase of undifferentiated basal cells and, associated with the E-cadherin immunoreactivity reduction in estrogenized animals [30], could predispose to the long-term epithelial-mesenchymal transition (EMT) process.

Estrogenic activity can also be shown with the use of synthetic estrogens, such as ethinylestradiol (EE), used as a contraceptive and in hormonal therapies, widely dispersed in the environment due to its low 
degradation [54]. Falleiros-Júnior et al. [55] and Perez et al. [56] showed that both neonatal $(10 \mu \mathrm{g} / \mathrm{kg})$ and pubertal exposure $(15 \mu \mathrm{g} /$ $\mathrm{kg}$ ), respectively, promote repercussions on the adult prostate. Both studies reported the presence of hyperplastic areas associated with stromal and luminal inflammatory foci. In addition, greater vimentin immunoreactivity was observed in the cytoplasm of epithelial cells and in inflammatory foci in the stroma of animals exposed to EE [56]. Vimentin is one of the main intermediate filaments proteins related to mesenchymal characteristics and increased motility, and is an important marker of EMT [57]. As reviewed by Ivaska et al. [58], vimentin acts on cell-cell and cell-stroma interactions, and regulates the integrins function, important transmembrane receptors of cellular adhesion, whose cytoplasmic pore connects to the cytoskeleton, turns extracellular signals into cellular responses, and culminates in proliferation and migration changes.

Increased vimentin expression and reduced E-cadherin expression were observed in the dorsolateral prostate of aged rats orally exposed to BPA (10, 30 and $90 \mu \mathrm{g} / \mathrm{kg}$ ) over 3 months [6]. Exposure to the plasticizer was responsible for increasing the estrogen/androgen ratio, triggering an inflammatory process, which consequently up-regulated the expression of TGF- $\beta 1$ pathway regulatory proteins such as Snail, Twist and Wnt [6]. Brandt et al. [59] and Bernardo et al. [60] also reported changes in the ventral prostatic epithelial structure of adult rats after BPA exposure ( 25 and $250 \mu \mathrm{g} / \mathrm{kg}$ ) during the gestational period, with the presence of inflammatory infiltrates of mononuclear cells in the stroma, inflammatory reactive atypia and PIN (Prostatic Intraepithelial Neoplasia).

TGF- $\beta 1 /$ Smad pathway up-regulation and consequent increased EMT process was observed in the lateral prostate of mice intoxicated with cadmium $(0.2 \mathrm{mg} / \mathrm{kg})$ subcutaneously [61].Cadmium is a metal constituent in tobacco and tobacco smoke and has been classified as a group 1 carcinogen and a proinflammatory inducer [62]. Cadmium was responsible for increased levels of vimentin mRNA and decreased Ecadherin mRNA, as well as the promotion of the inflammatory process, with greater expression of proinflammatory cytokines, such as IL-1 $\beta$, IL6 and TNF- $\alpha[61]$.

\section{Epithelial-Mesenchymal Transition (EMT): role of EDCs on in vivo and in vitro models}

In the prostate development and homeostasis, the reciprocal signaling between prostate epithelium and stroma compartments is fundamental. Similarly, interactions between tumor cells and stromal constituents are central to the carcinogenesis progression and tumor cell invasion, dissemination, and growth in distant sites [63].

Although EDCs are associated with an induction of genetic and epigenetic changes that culminate in the initiation and progression of some types of cancer $[64,65]$, some of them can contribute with metastasis in hormone dependent cancers [66-68]. According to Lee et al. [69] 'metastasis occurs when cancer cells dissociate from the cell to cell junction in a primary tumor site, enter the bloodstream or lymphatic system, and migrate to a secondary site $[70,71]$. Metastasis is extensively studied because it is essential in cancer progression and the major cause of death from cancer. There are several in vitro studies with hormone dependent cancer cells and environmental EDCs, performed to understand their role in propitiating and accelerating the EMT $[3,11,12]$. The EMT is a well-described process by which epithelial cells lose their cell polarity and cell-cell adhesion and acquire mesenchymal phenotype, enhancing the migratory ability of cancer cells for metastasis [72].

Collectively, the majority of previous studies revealed that BPA, phthalates, TCDD, and other EDCs have the potential to induce cancer metastasis through regulating EMT (epithelial-mesenchymal transition) markers and migration via several signaling pathways associated with the EMT program [69].

Considering the carcinomas that constitute almost $90 \%$ of cancers, upon oncogenic transformation, the process begins with the E-cadherin downregulation that held the epithelial cells together as a well differentiated cell society [73]. Simultaneous to the E-cadherin downregulation is the conversion of the epithelial cells to mesenchymal cells [74]. Epithelial-mesenchymal transition allows the immotile and polarized epithelial cells to be converted into motile mesenchymal cells [75], and this process involves the breakdown of cell-to-cell or cell-toextracellular matrix adherence at the polarized epithelium lining [76]. E-cadherin loss can be caused through repression of its expression by transcription factors such as [77]: snail 1, snail 2 (commonly known as slug), ZEB1, ZEB2, Kruppel-like factor 8 (KLF8), Twist, lymphoid enhancer binding factor-1 (LEF-1), and fork-head box protein C2 (FOXC2) can bind to E-cadherin promoter and repress its transcription directly or indirectly [69]. The transcription factors such as snail, slug, twist and ZEB1/2 are some of the best characterized signaling molecules in biology that control EMT [78].

Phthalates have been found to be involved in cancer metastasis, a process that requires the EMT process. Di(2-ethylhexyl) phthalate (DEHP), the most abundant phthalate, was shown to increase cell proliferation, tumor mobility and invasiveness as well as inhibit gap and tight junctions to promote EMT [79] by regulating cell cycle genes and cathepsin D, a metastasis-related gene, via AR [69].

Regarding BPA, studies show that the biological effects change with the dose administered $[80,81]$. Besides that, in the rat prostate, which is multilobulated, there are indications that BPA exerts different effects between prostatic lobes. While Takashi [82] noticed an increase in dorsolateral prostate weight of rats exposed to BPA $(235 \mathrm{mg} / \mathrm{kg})$, Herath et al. [80] reported a decrease of weight in ventral lobe of rats treated with $3 \mathrm{mg} / \mathrm{kg}$, which means that its effect is lobe specific. A recent study shows that low doses of BPA $(30,90 \mu \mathrm{g} / \mathrm{kg})$ stimulate the EMT in the dorsolateral lobe of rats, in addition to its effect on cell proliferation and estrogen levels [6].

Adult NBL rats that were treated with BPA (15 and $320 \mathrm{mg}$, pellets) and testosterone over a period 32 weeks showed T-cell infiltration in the prostate epithelium associated with a disruption in HNF4- $\alpha$ genes network [83]. Activation of HNF4- $\alpha$ controls the switch between the transcriptional and adhesion functions of Wnt/ $\beta$-catenin [84]. The stabilization of $\beta$-catenin is a crucial event for the initiation of PIN-like lesions, while HNF4- $\alpha$ also regulates the EMT, a process involved in PIN development in a mouse model [84-86].

Recently, Huang et al. [6] exposed male Sprague-Dawley (5-7 weeks old) to BPA (10, 30 and $90 \mu \mathrm{g} / \mathrm{kg} /$ day) for 3 months. Besides the E-cadherin downregulation, the microarray analyzis of 89 EMT-related genes showed that 26 were upregulated, such as snails, twist, transforming growth factor $\beta 1$ (TGF- $\beta 1$ ) and vimentin. Snails participate in the inhibition of E-cadherin expression to start EMT and can also inhibit the transcription of cytokeratin-8, a epithelial cell marker. A vital role in EMT is also exerted by TGF- $\beta 1$ that can directly activate smad 3, thus stimulating the expression of snails $[87,88]$.

Yong et al. [89] demonstrated that PTCH, a critical gene of Hedgehog pathway, was upregulated in a dose-response way by Mono2-ethyhexyl phthalate (MEHP) in LNCaP prostate cancer cells. Hedgehog pathway has an important role in the prostate cancer progression and its activation can modulate a variety of transcription factors such as the SNAIL 1 protein (Zinc finger protein SNAI1). SNAIL, besides inhibiting E-cadherin, also disrupts the tight junctions proteins, which compromise the epithelial homeostasis [90].

Pesticides have been associated with prostate carcinogenesis and their persistence in the environment could promote tumor growth and invasion. Potti and Sehgal [91] demonstrated that PZ-7 prostate cancer cells exposed to herbicide and insecticides showed disrupted expression of urokinase (uPA) and its receptor (UPAR). Briefly, uPA-uPAR interaction induces cellular motility, modulation of adhesion proteins, intracellular signaling and proliferation. According Potti and Sehgal [91], the herbicide Roundup $\left(10^{-6} \mathrm{M}\right)$ and the insecticides, Lorsban $\left(10^{-6} \mathrm{M}\right)$ and Warrior $\left(10^{-5} \mathrm{M}\right)$ induced significant uPA protein expression; 
Table 1

EDCs and its effects on prostate.

\begin{tabular}{|c|c|c|c|}
\hline Endocrine Disruptor & Experimental Model & Alterations & Reference \\
\hline \multirow[t]{2}{*}{ Ethinylestradiol } & $\begin{array}{l}\text { Gerbil. } 10 \mu \mathrm{g} / \mathrm{kg} \text {, orally, in lactating females. } \\
\text { Neonatal (days 1-10) exposure }\end{array}$ & Hyperplasia focus with the presence of inflammatory cells & $\begin{array}{l}\text { Falleiros-Junior et al. } \\
\text { [55] }\end{array}$ \\
\hline & $\begin{array}{l}\text { Gerbil. } 15 \mu \mathrm{g} / \mathrm{kg} \text {, orally. Post-natal (days 42-49) } \\
\text { exposure }\end{array}$ & $\begin{array}{l}\text { Increased immunoreactivty to vimentin and presence of } \\
\text { inflammatory cells }\end{array}$ & Perez et al. [56] \\
\hline Estradiol Benzoate & $\begin{array}{l}\text { Sprague-Dawley Rats. } 25 \mu \mathrm{g} \text { subcutaneously. } \\
\text { Neonatal (days } 1,3,5 \text { ) exposure }\end{array}$ & $\begin{array}{l}\text { Decreased Cx-32 and E-cadherin expression, altered } \\
\text { localization of } \mathrm{Cx}-32 \text {, presence of inflammatory cells }\end{array}$ & Habermann et al. [30] \\
\hline $\begin{array}{l}\text { 17 } \beta \text {-estradiol 3-benzoate (EB)or } \\
\text { Bisphenol A (BPA) }\end{array}$ & $\begin{array}{l}\text { Sprague-Dawley Rats. EB: } 0.1 \text { and } 2500 \mu \mathrm{g} / \mathrm{kg} \text {; } \\
\text { BPA: } 10 \mu \mathrm{g} / \mathrm{kg} \text {, subcutaneously. Neonatal (days } \\
1,3,5 \text { ) exposure }\end{array}$ & Increased susceptibility to prostate neoplastic lesions & Ho et al. [44] \\
\hline \multirow[t]{4}{*}{ Bisphenol A (BPA) } & $\begin{array}{l}\text { Wistar Rats. } 25 \mu \mathrm{g} / \mathrm{Kg} / \text { day, } 250 \mu \mathrm{g} / \mathrm{Kg} / \text { day. } \\
\text { Prenatal (days 8-23) exposure. }\end{array}$ & Altered differentiation pattern of periductal stromal cells & Ramos et al. [46] \\
\hline & $\begin{array}{l}\text { Sprague-Dawley Rats. } 10,30 \text { and } 90 \mu \mathrm{g} / \mathrm{kg} \text {, } \\
\text { orally.Post-natal exposure during } 3 \text { months }\end{array}$ & $\begin{array}{l}\text { Increased vimentin, decreased e-cadherin and occurrence of } \\
\text { EMT }\end{array}$ & Huang et al. [6] \\
\hline & $\begin{array}{l}\text { Sprague-Dawley Rats. } 25 \text { and } 250 \mu \mathrm{g} / \mathrm{kg} \text {, } \\
\text { orally.Fetal (gestational days 10-21) exposure }\end{array}$ & $\begin{array}{l}\text { Infiltrate of mononuclear cells in the stroma, inflammatory } \\
\text { lesions and PIN }\end{array}$ & $\begin{array}{l}\text { Brandt et al. [59] and } \\
\text { Bernardo et al. [60] }\end{array}$ \\
\hline & $\begin{array}{l}\text { NBL rats. } 15 \text { and } 320 \mathrm{mg} \text {, surgically implanted } \\
\text { capsules. Adult exposure for } 32 \text { weeks }\end{array}$ & $\begin{array}{l}\text { Infiltration of T-cells in the prostate epithelium and } \\
\text { deregulation of the HNF4-alpha/Wnt- } \beta \text {-catenin. }\end{array}$ & Lam et al. [83]. \\
\hline Tributyltin (TBT) & $\begin{array}{l}\text { Sprague-Dawley Rats. } 2.5,10 \text {, and } 20 \mathrm{mg} / \mathrm{kg} \text { by } \\
\text { gavage. Fetal exposure (gestational days } 0-19 \text { ) }\end{array}$ & $\begin{array}{l}\text { Decreased E-cadherin, claudin-1and increased claudins }-3 \text {, } \\
-8 \text { gene expression and altered localization of claudin- } 1\end{array}$ & Barthelemy et al. [23] \\
\hline \multirow[t]{2}{*}{ Flutamide } & $\begin{array}{l}\text { Pigs (Large White } \times \text { Polish Landrace). } 5 \text { doses of } \\
50 \mathrm{mg} / \mathrm{kg} \text { subcutaneously. Early postnatal (days } \\
2-10 \text { ) and prepubertal (days 90-98) exposure }\end{array}$ & $\begin{array}{l}\text { Decreased E-cadherin and increased } \beta \text {-catenin gene } \\
\text { expression and altered localization of } \beta \text {-catenin }\end{array}$ & Gorowska et al. [36] \\
\hline & $\begin{array}{l}\text { Pigs (Large White } \times \text { Polish Landrace). } 5 \text { doses of } \\
50 \mathrm{mg} / \mathrm{kg} \text { subcutaneously. Fetal (gestational days } \\
20-28 \text { ) and neonatal (days 2-10) exposure }\end{array}$ & $\begin{array}{l}\text { Reduction of the luminal compartment, inflammatory } \\
\text { alterations, increased } \mathrm{Cx}-43 \text { gene and protein expression, } \\
\text { and altered localization of } \mathrm{Cx}-43\end{array}$ & Hejmej et al. [37] \\
\hline $\begin{array}{l}\text { 2,3,7,8-tetrachlorodibenzo-p-dioxin } \\
\text { (TCDD) }\end{array}$ & C57BL/6 J mouse embryos. $5 \mathrm{~mL} / \mathrm{kg}$. & Compromised branching of the developing prostate & Schneider et al. [48] \\
\hline \multirow[t]{3}{*}{ Cadmium } & $\begin{array}{l}\text { Wistar rats. } 0.2 \mathrm{mg} / \mathrm{kg} \text {, subcutaneously. } \\
\text { Prepubertal exposure for } 15 \text { days }\end{array}$ & $\begin{array}{l}\text { Increased vimentin, IL-1 } \beta \text {, IL- } 6 \text {, TNF- } \alpha \text { and decreased e- } \\
\text { cadherin }\end{array}$ & Du et al. [61] \\
\hline & RWPE- 1 cells. 5-10 $\mu$ M. Exposure for 48 and $72 \mathrm{~h}$ & Increased $\mathrm{Cx} 43$ expression and cell proliferation & Liu et al. [95] \\
\hline & $\begin{array}{l}\text { Normal Prostate Stem Cells (NSC, WPE-stem) co- } \\
\text { cultivated with Cadmiun-transformed malignant } \\
\text { epithelial cells (Cd-MEC) for two weeks. }\end{array}$ & $\begin{array}{l}\text { NSC acquired cancer stem cells characteristics via a } \\
\text { microenvironment that contains soluble factors derived } \\
\text { from MECs originally transformed by the cadmium. } \\
\text { Increased Vimentin and decreased E-cadherin }\end{array}$ & $\mathrm{Xu}$ et al. [92] \\
\hline $\begin{array}{l}\text { Mono-2-ethyhexyl phthalate } \\
\text { (MEHP) }\end{array}$ & $\begin{array}{l}\text { LNCaP prostate cancer cells. 1, 5, } 10 \text { and } 25 \mu \mathrm{M} \text {. } \\
\text { Exposure for } 6 \text { and } 9 \text { days }\end{array}$ & $\begin{array}{l}\text { Up-regulatedPTCH gene (Hedgehog pathway)/SNAIL } \\
\text { protein - induce EMT decreasing E-cadherin and tight } \\
\text { junctions }\end{array}$ & Yong et al. [89] \\
\hline $\begin{array}{l}\text { Herbicide Roundup and the } \\
\text { insecticides, Lorsban and } \\
\text { Warrior }\end{array}$ & $\begin{array}{l}\text { PZ-7 prostate cancer cells. Roundup, Lorsban: } \\
10^{-6} \mathrm{M} ; \text { Warrior: } 10^{-5} \mathrm{M} \text {. Exposure for } 3 \text { days }\end{array}$ & $\begin{array}{l}\text { increased uPA and uPAR protein expression-modulation of } \\
\text { adhesion proteins }\end{array}$ & Potti \& Sehgal. [91] \\
\hline
\end{tabular}

additionally, Lorsban and Warrior also increased uPAR expression. These results suggested that a mixture of some herbicides could increases the metastatic potential of tumor cells.

$\mathrm{Xu}$ et al. [92] showed that prostatic normal stem cells (NSCs; WPE stem) can acquire an oncogenic phenotype when they are co-cultivated with cadmium-transformed malignant epithelial cells (Cd-MECs) but not with N-methyl- $N$-nitrosourea-transformed MECs (MNU-MECs). The results from this in vitro experiment provided evidence that NSCs could be influenced by soluble factors produced by Cd-MECs, and it is likely that inflammatory factors such as TGF $\beta 1$ may play an important role in this malignant transformation. During the co-cultured with Cd-MECs protocol, NSCs acquired the morphology and molecular markers of EMT, a higher expression of snail, twist and vimentin concomitant with E-cadherin downregulation [92]. It is suggested that cadmium has a crucial role in the oncogenic transformation of prostatic normal stem cells into cancer stem cells which involves multiple factors, including alteration on adherent and tight junction properties [15], epigenetic changes, oxidative stress, and inflammation [93].

Recently, Zhang et al. [94] related the Cx-43 with oncogenicity and metastatic potential in four different prostate cancer cells lines. Considering this, Liu et al. [95] demonstrated that cadmium $(5-10 \mu \mathrm{M})$ was able to increase $\mathrm{Cx}-43$ expression, probably by a mechanism linked to androgen receptor (AR), and promoted proliferation in RWPE-1 cells. The authors concluded that cadmium incites cell proliferation, mediated by $\mathrm{Cx}-43$ expression through an effect on cell cycle-associated proteins [95]. This relationship between AR and Cx-43 is in agreement with reviewed data by Boucher et al. [29] that presented studies showing an increase in $\mathrm{Cx}-43$ expression after pharmacological or physical castration, being associated with increased expression of apoptotic markers and reduced cell proliferation.

\section{Summary of the best established mechanisms and mechanisms that need to be investigated}

Herein we review the current state-of-the-art mechanisms in terms of how the increasing exposure to environmental xenobiotics has been associated with the occurrence of male reproductive disorders. Some mechanisms by which xenobiotics interfere with cellular communication molecules during prostate morphogenesis need to be elucidate because many of these pathways of development appear to be correlated with the initiation of alterations in the adult prostate. In the Table 1, we summarize the drugs, doses and their effects on cellular junctions discussed in this review (Table 1). Additionally, the Fig. 2 illustrates a prostatic epithelium and its cellular junctions that are EDCs targets.

A collection of studies revealed that BPA, phthalates, TCDD, tributyltin, estradiol benzoato and other EDCs have the potential to induce cancer metastasis through regulating EMT, interfering in the structural organization of the prostatic epithelium, its adhesive molecules and cell-to-cell communication. In relation to signaling pathways modulated by some deregulators, there is a need for further studies. TCDD deregulate factors of the Wnt/ $\beta$-catenin pathaway which could interrupt paracrine signaling towards the prostate epithelium. Likewise, Schneider et al. [48] described Cadmium as responsible for increased 


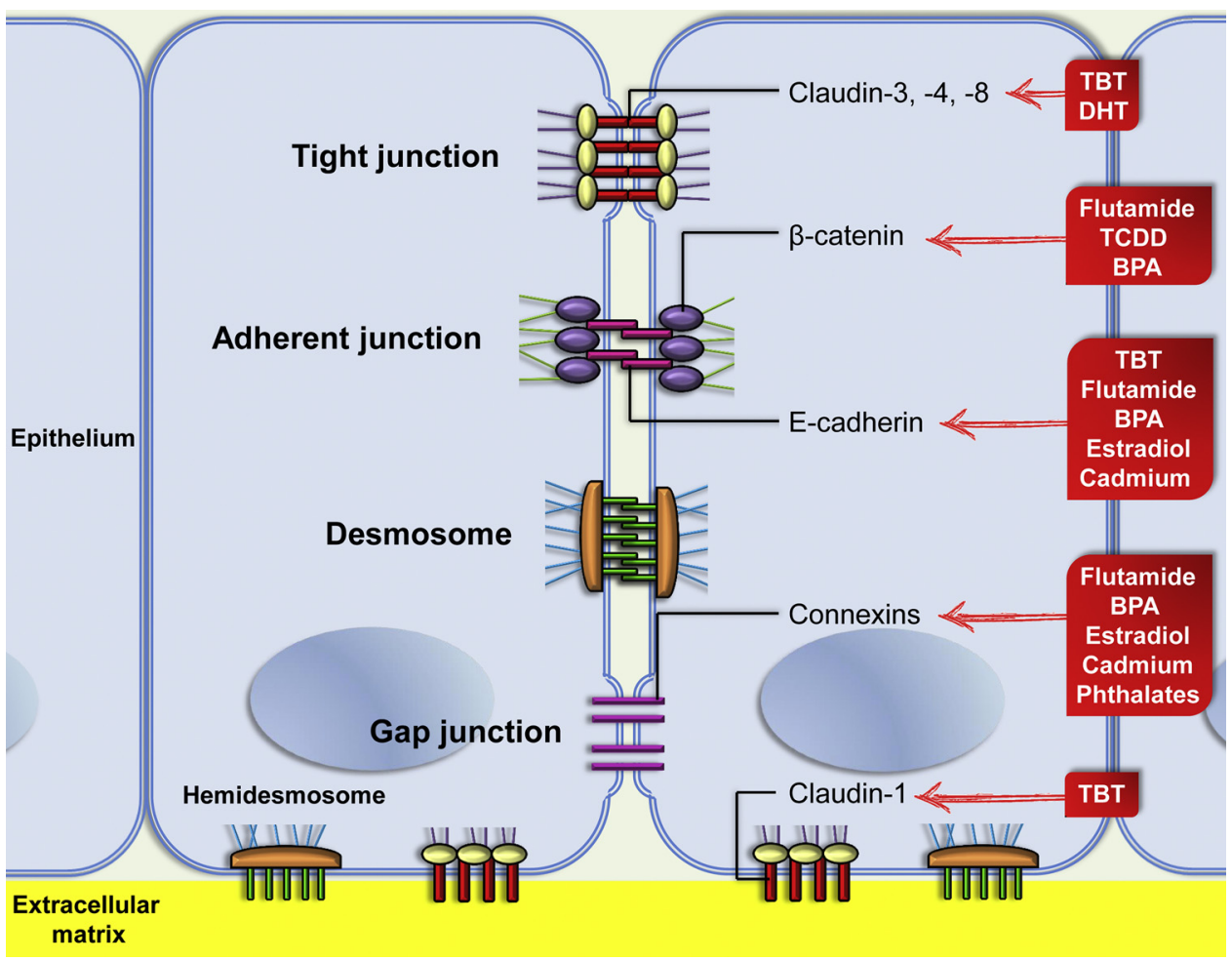

Fig. 2. Scheme illustrating the main EDCs and its actions on cell junction proteins of prostatic epithelium.

levels of vimentin mRNA and decreased E-cadherin mRNA in addition to the TGF- $\beta 1 /$ Smad pathway up-regulation, but the mechanism behind the process needs to be clarified [15]. There are plenty of studies showing that the EDCs exposure has a central role in the disruption of cell polarity, increased cell motility and invasion and EMT processes. However, some of them need to be investigated more to understand the long-term consequences of their inter-actions during critical developmental periods of the male reproductive systems and the mechanisms that govern these changes [96].

Additional studies involving more complex experimental designs that approximate human exposure are also needed. It is important to note that most of the studies cited in this review emphasized the use of isolated drugs, in a different way from the Expossoma concept, initially proposed by Wild [97] and refined by Miiler and Jones [98], defined as the set of environmental exposures and associated biological responses throughout life. Rather than assessing one to one or groups of two or three EDCs, the goal of this approach is to simultaneously analyze as many compounds as possible in relevant doses and over long periods, interacting with other oncogenic insults, such as aging or exposure to other carcinogens, that trigger the progression of prostate cancer later in life.

\section{References}

[1] F.S. vom Saal, B.G. Timms, M.M. Montano, P. Palanza, K.A. Thayer, S.C. Nagel, M.D. Dhar, V.K. Ganjam, S. Parmigiani, W.V. Welshons, Prostate enlargement in mice due to fetal exposure to low doses of estradiol or diethylstilbestrol and opposite effects at high doses, Proc. Natl. Acad. Sci. U.S.A. 94 (1997) 2056-2061.

[2] W.R. Scarano, F.C. Toledo, M.T. Guerra, S.G.P. Campos, L.A. Justulin Jr, S.L. Felisbino, J.A. Anselmo-Franci, S.R. Taboga, W.G. Kempinas, Long-term effects of developmental exposure to di-n-butyl-phthalate (DBP) on rat prostate: proliferative and inflammatory disorders and a possible role of androgens, Toxicology 262 (2009) 215-223, https://doi.org/10.1016/j.tox.2009.06.011.

[3] Y.S. Kim, K.A. Hwang, S.H. Hyun, K.H. Nam, C.K. Lee, K.C. Choi, Bisphenol A and nonylphenol have the potential to stimulate the migration of ovarian cancer cells by inducing epithelial-mesenchymal transition via an estrogen receptor dependent pathway, Chem. Res. Toxicol. 28 (2015) 662-671, https://doi.org/10.1021/ tx500443p.

[4] P.A. Cowin, E. Gold, J. Aleksova, M.K. O’Bryan, P.M. Foster, H.S. Scott, G.P. Risbridger, Vinclozolinexposure in utero induces post pubertal prostatitis and reduces sperm production via a reversible hormone-regulated mechanism, Endrocrinology 151 (2010) 783-792, https://doi.org/10.1210/en.2009-0982.

[5] X. Wang, Y. Wang, Q. Song, J. Wu, Y. Zhao, S. Yao, Z. Sun, Y. Zhang, In utero and lactational exposure to di(2-ethylhexyl) phthalate increased the susceptibility of prostate carcinogenesis in male offspring, Reprod. Toxicol. 20-69 (2017) 60-67, https://doi.org/10.1016/j.reprotox.2017.01.008.

[6] D.Y. Huang, C.C. Zheng, Q. Pan, S.S. Wu, X. Su, L. Li, J.H. Wu, Z.Y. Sun, Oral exposure of low-dose bisphenol A promotes proliferation of dorsolateral prostate and induces epithelial-mesenchymal transition in aged rats, Sci. Rep. 8 (2018) 490, https://doi.org/10.1038/s41598-017-18869-8.

[7] A. Hejmej, B. Bilinska, A role of junction-mediated interactions in cells of the male reproductive tract: Impact of prenatal, neonatal, and prepubertal exposure to antiandrogens on adult reproduction, Histol. Histopathol. 29 (2014) 815-830, https:// doi.org/10.14670/HH-29.815.

[8] R. Solecki, A. Kortenkamp, Å. Bergman, I. Chahoud, G.H. Degen, D. Dietrich, H. Greim, H. Håkansson, U. Hass, T. Husoy, M. Jacobs, S. Jobling, A. Mantovani, P. Marx-Stoelting, A. Piersma, V. Ritz, R. Slama, R. Stahlmann, M. van den Berg, R.T. Zoeller, A.R. Boobis, Scientific principles for the identification of endocrinedisrupting chemicals: a consensus statement, Arch. Toxicol. 91 (2017) 1001-1006, https://doi.org/10.1007/s00204-016-1866-9.

[9] M.F. Sweeney, N. Hasan, A.M. Soto, C. Sonnenschein, Environmental endocrine disruptors: effects on the human male reproductive system, Rev. Endocr. Metab. Disord. 16 (2015) 341-357, https://doi.org/10.1007/s11154-016-9337-4.

[10] A.R. Peixoto, T.M. Santos, J.Z. Brandt, F.K. Delella, B.F. Gonçalves, S.G. Campos, S.R. Taboga, W.J. Favaro, R.F. Domeniconi, W.R. Scarano, Gestational and lactational exposition to Di-N-butyl-phthalate (DBP) increases inflammation and preneoplastic lesions in prostate of wistar rats after carcinogenic N-methyl-N-nitrosourea (MNU) plus testosterone protocol, Environ. Toxicol. 31 (2016) 1185-1195, https://doi.org/10.1002/tox.22126.

[11] X.L. Zhang, H.S. Wang, N. Liu, L.C. Ge, Bisphenol A stimulates the epithelial mesenchymal transition of estrogen negative breast cancer cells via FOXA1 signals, Arch. Biochem. Biophys. 585 (2015) 10-16, https://doi.org/10.1016/j.abb.2015. Arch. Bioch.

[12] K.H. Wang, A.P. Kao, C.C. Chang, T.C. Lin, T.C. Kuo, Bisphenol A-induced epithelial to mesenchymal transition is mediated by cyclooxygenase- 2 upregulation in human endometrial carcinoma cells, Reprod. Toxicol. 58 (2015) 229-233, https://doi.org/ 10.1016/j.reprotox.2015.10.011.

[13] B. Boyer, A.M. Vallés, N. Edme, Induction and regulation of epithelial-mesenchimal transitions, Biochem. Pharmacol. 60 (2000) 1091-1099, https://doi.org/10.1016/ S0006-2952(00)00427-5.

[14] J.P. Thiery, Epithelial-mesenchimal transitions in tumor progression, Nat. Rev. Cancer 2 (2002) 442-454, https://doi.org/10.1038/nrc822.

[15] J. Ochieng, G.N. Nangami, O. Ogunkua, I.R. Miousse, I. Koturbash, V. Odero-Marah, L. McCawley, P. Nangia-Makker, N. Ahmed, Y. Luqmani, Z. Chen, S. Papagerakis, G.T. Wolf, C. Dong, B.P. Zhou, D.G. Brown, A. Colacci, R.A. Hamid, C. Mondello, J. Raju, E.P. Ryan, J. Woodrick, I. Scovassi, N. Singh, M. Vaccari, R. Roy, S. Forte, L. Memeo, H.K. Salem, A. Amedei, R. Al-Temaimi, F. Al-Mulla, W.H. Bisson, 
S.E. Eltom, The impact of low-dose carcinogens and environmental disruptors on tissue invasion and metastasis, Carcinogenesis 36 (2015) S128-S159, https://doi. org/10.1093/carcin/bgv034.

[16] S.W. Hayward, G.R. Cunha, R. Dahiya, Normal development and carcinogenesis of the prostate: a unifying hypothesis, Ann. N. Y. Acad. Sci. 784 (1996) 50-62, https:// doi.org/10.1111/j.1749-6632.1996.tb16227.x.

[17] B.G. Timms, T.J. Mohs, L.J. Didio, Ductal budding and branching patterns in the developing prostate, J. Urol. 151 (1994) 1427-1432, https://doi.org/10.1016/ S0022-5347(17)35273-4.

[18] P.C. Marker, A.A. Donjacour, R. Dahiya, G.R. Cunha, Hormonal, cellular, and molecular control of prostatic development, Dev. Biol. 253 (2003) 165-174, https:// doi.org/10.1016/S0012-1606(02)00031-3.

[19] Y. Sugimura, G.R. Cunha, A.A. Donjacour, Morphogenesis of ductal networks in the mouse prostate, Biol. Reprod. 34 (1986) 961-971.

[20] J.T. Isaacs, Y. Furuya, R. Berges, The role of androgen in the regulation of programmed cell death/apoptosis in normal and malignant prostatic tissue, Semin. Cancer Biol. 5 (1994) 391-400.

[21] S.J. Ellem, G.P. Risbridger, The dual, opposing roles of estrogen in the prostate, Ann. N. Y. Acad. Sci. 1155 (2009) 174-186, https://doi.org/10.1111/j.1749-6632. 2009.04360.x.

[22] G.R. Cunha, W. Ricke, A. Thomson, P.C. Marker, G. Risbridger, S.W. Hayward, Y.Z. Wang, A.A. Donjacour, T. Kurita, Hormonal, cellular, and molecular regulation of normal and neoplastic prostatic development, J. Steroid Biochem. Mol. Biol. 92 (2004) 221-236, https://doi.org/10.1016/j.jsbmb.2004.10.017.

[23] J. Barthelemy, A. Adeeko, B. Robaire, D.G. Cyr, In Utero exposure to Tributyltin alters the expression of e-cadherin and localization of claudin-1 in intercellular junctions of the rat ventral prostate, Mol. Reprod. Dev. 74 (2007) 455-467, https:// doi.org/10.1002/mrd.20537.

[24] N. Sakai, H. Chiba, H. Fujita, Y. Akashi, M. Osanai, T. Kojima, N. Sawada, Expression patterns of claudin family of tight junction proteins in the mouse prostate, Histochem. Cell Biol. 127 (2007) 457-462, https://doi.org/10.1007/ s00418-007-0269-7.

[25] K.P. Keil, L.L. Abler, V. Mehta, H.M. Altmann, J. Laporta, E.H. Plisch, M. Suresh, L.L. Hernandez, C.M. Vezina, DNA methylation of E-cadherin is a priming mechanism for prostate development, Dev. Biol. 387 (2014) 142-153, https://doi.org/ 10.1016/j.ydbio.2014.01.020.

[26] M. Jaggi, T. Nazemi, N.A. Abrahams, J.J. Baker, A. Galich, L.M. Smith, K.C. Balaji, $\mathrm{N}$-cadherin switching occurs in high Gleason grade prostate cancer, Prostate 66 (2006) 193-199, https://doi.org/10.1002/pros.20334.

[27] R. Bruzzone, T. White, D. Paul, Connections with connexins: the molecular basis of direct intercellular signaling, Eur. J. Biochem. 238 (1996) 1-27, https://doi.org/10. 1111/j.1432-1033.1996.0001q.x.

[28] J.C. Hervé, Gap junction channels: from protein genes to diseases, Prog. Biophys Mol. Biol. 94 (2007) 1-4, https://doi.org/10.1016/j.pbiomolbio.2007.03.012.

[29] J. Boucher, A. Monvoisin, J. Vix, M. Mesnil, D. Thuringer, F. Debiais, L. Cronier, Connexins, important players in the dissemination of prostate cancer cells, BiochimBiophysActa 1 (2018) 202-215, https://doi.org/10.1016/j.bbamem.2017. 06.020 .

[30] H. Habermann, W.Y. Chang, L. Birch, P. Mehta, G.S. Prins, Developmental exposure to estrogens alters epithelial cell adhesion and gap junction proteins in the adult rat prostate, Endocrinology 142 (2001) 359-369, https://doi.org/10.1210/endo.142. 1.7893.

[31] J. Czyz, K. Szpak, Z. Madeja, The role of connexins in prostate cancer promotion and progression, Nat. Rev. Urol. 9 (2012) 274-282, https://doi.org/10.1038, nrurol.2012.14.

[32] J. Meng, E.A. Mostaghel, F. Vakar-Lopez, B. Montgomery, L. True, P.S. Nelson, Testosterone regulates tight junction proteins and influences prostatic autoimmune responses, Horm. Cancer 2 (2011) 145-156, https://doi.org/10.1007/s12672-0100063-1.

[33] J.Y. Zheng, D. Yu, M. Foroohar, E. Ko, J. Chan, N. Kim, R. Chiu, S. Pang, Regulation of the expression of the prostate-specific antigen by claudin-7, J. MembrBiol. 194 (2003) 187-197, https://doi.org/10.1007/s00232-003-2038-4.

[34] T.M. Rowlands, J.M. Symonds, R. Farookhi, O. Blaschuk, Cadherins: crucial regulators of structure and function in reproductive tissues, Rev. Reprod. 5 (2000) $53-61$.

[35] H.T. Huynh, L. Alpert, D.W. Laird, G. Batist, L. Chalifour, M.A. Alaoui-Jamali, Regulation of the gap junction connexin 43 gene by androgens in the prostate, $\mathrm{J}$ Mol. Endocrinol. 26 (2001) 1-10.

[36] E. Gorowska, K. Chojnacka, M. Zarzycka, B. Bilinska, A. Hejmej, Postnatal exposure to flutamide affects CTNNB1 and CDH1gene expression in adult pig epididymis and prostate and alters metabolism of testosterone, Andrology 2 (2014) 186-197, https://doi.org/10.1111/j.2047-2927.2013.00172.x.

[37] A. Hejmej, E. Gorowska, M. Kotula-Balak, K. Chojnacka, M. Zarzycka, J. Zając, B. Bilinska, Androgen signaling disruption during fetal and postnatal development affects androgen receptor and connexin 43 expression and distribution in adult boar prostate, Biomed Res. Int. 2013 (2013) 407678, , https://doi.org/10.1155/2013/ 407678.

[38] Y. Yamabe, A. Hoshino, N. Imura, T. Suzuki, S. Himeno, Enhancement of androgendependent proliferation by tributyltin and triphenyltin in human prostate cancer cells, ToxicolApplPharmacol 169 (2000) 177-184, https://doi.org/10.1006/taap. 2000.9067.

[39] G.S. Prins, Neonatal estrogen exposure induces lobe-specific alterations in adult rat prostate androgen receptor expression, Endocrinology 130 (1992) 3703-3714, https://doi.org/10.1210/endo.130.6.1597166.

[40] C. Gupta, Reproductive malformation of the male offspring following maternal exposure to estrogenic chemicals, Proc. Soc. Exp. Biol. Med. 224 (2000) 61-68.
[41] G.S. Prins, Developmental estrogenization of the prostate gland, in: R.K. Naz (Ed.), Prostate: Basic and Clinical Aspects. CRC Press, Boca Raton, FL, 1997, pp. 247-265.

[42] P.P. Mehta, C. Perez-Stable, M. Nadji, M. Mian, K. Asotra, B.A. Roos, Suppression of human prostate cancer cell growth by forced expression of connexin genes, Dev. Genet. 110 (1999) 91-110.

[43] J.A. Taylor, C.A. Richter, A. Suzuki, H. Watanabe, T. Iguchi, K.R. Coser, T. Shioda, F.S. vomSaal, Dose-Related Estrogen Effects on Gene Expression in Fetal Mouse Prostate Mesenchymal Cells, PLoS ONE 7 (10) (2012) e48311, , https://doi.org/10. 1371/journal.pone.0048311.

[44] S.M. Ho, W.Y. Tang, J.B. Frausto, G.S. Prins, Developmental exposure to estradiol and bisphenolA increase susceptibility to prostate carcinogenesis and epigenetically regulates phosphodiesterase type 4 variant 4, Cancer Res. 66 (2006) 5624-5632, https://doi.org/10.1158/0008-5472.CAN-06-0516.

[45] G. Schonfelder, W. Wittfoht, H. Hopp, C.E. Talsness, M. Paul, I. Chahoud, Paren bisphenol A accumulation in the human maternal-fetal-placental unit, Environ. Health Perspect. 110 (2005) A703-A707.

[46] J.G. Ramos, J. Varayoud, C. Sonnenschein, A.M. Soto, De Toro M. Muñoz E.H. Luque, Prenatal exposure to low doses of bisphenol A alters the periductal stroma and glandular cell function in the rat ventral prostate, Biol. Reprod. 65 (2001) 1271-1277.

[47] C.M. Vezina, T.M. Lin, R.E. Peterson, AHR signaling in prostate growth, morphogenesis, and disease, Biochem. Pharmacol. 77 (4) (2009) 566-576, https://doi.org/ 10.1016/j.bcp.2008.09.039.

[48] A.J. Schneider, A.M. Branam, R.E. Peterson, Intersection of AHR and Wnt signaling in development, health, and disease, Int. J. Mol. Sci. 10-15 (2014) 17852-17885, https://doi.org/10.3390/ijms151017852.

[49] J.E. Elkahwaji, R.J. Hauke, C.M. Brawner, Chronic bacterial inflammation induces prostatic intraepithelial neoplasia in mouse prostate, B. J. Cancer 101 (2009) 1740-1748, https://doi.org/10.1038/sj.bjc.6605370.

[50] E. Yatkin, J. Bernoulli, E. Talvitie, R. Santti, Inflammation and epithelial alterations in rat prostate: impact of the androgen to oestrogen ratio, Int. J. Androl. 32 (2009) 399-410, https://doi.org/10.1111/j.1365-2605.2008.00930.x.

[51] R.J. Kavlock, G.P. Daston, C. DeRosa, P. Fenner-Crisp, L.E. Gray, S. Kaattari, G. Lucier, M. Luster, M.J. Mac, C. Maczka, R. Miller, J. Moore, R. Rolland, G. Scott, D.M. Sheehan, T. Sinks, H.A. Tilson, Research needs for the risk assessment of health and environmental effects of endocrine disruptors: a report of the U.S. EPAsponsored workshop, Environ. Health Perspect. 104 (1996) 715-740.

[52] R. Kiyama, Y. Wada-Kiyama, Estrogenic endocrine disruptors: Molecular mechanisms of action, Environ. Int. 83 (2015) 11-40, https://doi.org/10.1016/j.envint. 2015.05.012.

[53] G.S. Prins, L. Birch, H. Habermann, W.Y. Chang, C. Tebeau, O. Putz, C. Bieberich, Influence of neonatal estrogens on rat prostate development, Reprod. Fertil. Dev. 13 (2001) 241-252, https://doi.org/10.1071/RD00107.

[54] A.Z. Aris, A.S. Shamsuddin, S.M. Praveena, Occurrence of 17a-ethynylestradiol (EE2) in the environment and effect on exposed biota: a review, Environ. Int. 69 (2014) 104-119, https://doi.org/10.1016/j.envint.2014.04.011.

[55] L.R. Falleiros-Júnior, A.P. Perez, S.R. Taboga, F.C. Dos Santos, P.S. Vilamaior, Neonatalexposure to ethinylestradiolincreasesventralprostategrowth and promotesepithelialhyperplasia and inflammation in adultmalegerbils, Int. J. Exp. Pathol. 97 (2016) 380-388, https://doi.org/10.1111/iep.12208.

[56] A.P. Perez, M.F. Biancardi, C.R. Caires, L.R. Falleiros Jr, R.M. Góes, F.C. Santos, S.R. Taboga, Pubertalexposure to ethinylestradiolpromotesdifferenteffects on the morphology of the prostate of the male and femalegerbil during aging, Environ. Toxicol. 32 (2017) 477-489, https://doi.org/10.1002/tox.22252.

[57] M.G. Mendez, S. Kojima, R.D. Goldman, Vimentin induces changes in cell shape, motility, and adhesion during the epithelial to mesenchymal transition, FASEB J. 24 (2010) 1838-1851, https://doi.org/10.1096/fj.09-151639.

[58] J. Ivaska, H.M. Pallari, J. Nevo, J.E. Eriksson, Novel functions of vimentin in cell adhesion, migration, and signaling, Exp. Cell Res. 313 (2007) 2050-2062, https:// doi.org/10.1016/j.yexcr.2007.03.040.

[59] J.Z. Brandt, L.T. Silveira, T.F. Grassi, J.A. Anselmo-Franci, W.J. Fávaro, S.L. Felisbino, L.F. Barbisan, W.R. Scarano, Indole-3-carbinolattenuates the deleteriousgestationaleffects of bisphenol A exposure on the prostategland of maleF1rats, Reprod. Toxicol. 43 (2014) 56-66, https://doi.org/10.1016/j.reprotox. 2013.11.001.

[60] B.D. Bernado, J.Z. Brandt, T.F. Grassi, L.T. Silveira, W.R. Scarano, L.F. Barbisan, Genisteinreduces the noxiouseffects of in uterobisphenol A exposure on the ratprostategland at weaning and in adulthood, Food Chem. Toxicol. 84 (2015) 64-73, https://doi.org/10.1016/j.fct.2015.07.011.

[61] L. Du, Y. Lei, J. Chen, H. Song, X. Wu, PotentialAmeliorativeEffects of QingYeDanAgainstCadmiumInducedProstatic Deficits via Regulating Nrf-2/HO-1 and TGF- $\beta 1 /$ Smad Pathways, Cell. Physiol. Biochem. 43 (2017) 1359-1368, https://doi.org/10.1159/000481847.

[62] P. Richter, O. Faroon, R.S. Pappas, Cadmium and Cadmium/Zinc ratios and tobacco-related morbidities, Int. J. Environ. Res. Public Health 14-10 (2017) E1154, https://doi.org/10.3390/ijerph14101154.

[63] C. Levesque, P.S. Nelson, Cellular Constituents of the Prostate stroma: key contributors to prostate cancer progression and therapy resistance, Cold Spring Harb. Perspect. Med. (2017), https://doi.org/10.1101/cshperspect.a030510 pii: a030510

[64] S.C. Kang, B.M. Lee, DNA methylation of estrogen receptor alpha gene by phthalates, J. Toxico. Environ. Health Part A 68 (2005) 1995-2003, https://doi.org/10 1080/15287390491008913.

[65] S. Singh, S.S. Li, Epigenetic effects of environmental chemicals bisphenol A and phthalates, Int. J. Mol. Sci. 13 (2012) 10143-10153, https://doi.org/10.3390/ ijms130810143. 
[66] S.J. In, S.H. Kim, R.E. Go, K.A. Hwang, K.C. Choi, Benzophenone-1 and nonylphenol stimulated MCF-7 breast cancer growth by regulating cell cycle and metastasisrelated genes via an estrogen receptor alpha-dependent pathway, J. Toxicol. Environ. Health A 78 (2015) 492-505, https://doi.org/10.1080/15287394.2015. 1010464.

[67] Z.J. Chen, X.L. Yang, H. Liu, W. Wei, K.S. Zhang, H.B. Huang, J.P. Giesy, H.L. Liu, J. Du, H.S. Wang, Bisphenol A modulates colorectal cancer protein profile and promotes the metastasis via induction of epithelial to mesenchymal transitions, Arch. Toxicol. 89 (2015) 1371-1381, https://doi.org/10.1007/s00204-014-1301-z.

[68] H.R. Lee, K.C. Choi, 4-tert-Octylphenol stimulates the expression of cathepsins in human breast cancer cells and xenografted breast tumors of a mouse model via an estrogen receptor-mediated signaling pathway, Toxicology 304 (2013) 13-20, https://doi.org/10.1016/j.tox.2012.10.012.

[69] H.M. Lee, K.A. Hwang, K.C. Choi, Diverse pathways of epithelial mesenchymal transition related with cancer progression and metastasis and potential effects of endocrine disrupting chemicals on epithelial mesenchymal transition process, Mol. Cell. Endocrinol. 457 (2017) 103-113, https://doi.org/10.1016/j.mce.2016.12. 026.

[70] G.P. Gupta, J. Massagué, Cancer metastasis: building a framework, Cell 127 (2006) 679-695, https://doi.org/10.1016/j.cell.2006.11.001.

[71] J. Wen, N.G. Nikitakis, R. Chaisuparat, T. Greenwell-Wild, M. Gliozzi, W. Jin, A. Adli, N. Moutsopoulos, T. Wu, G. Warburton, S.M. Wahl, Secretory leukocyte protease inhibitor (SLPI) expression and tumor invasion in oral squamous cell carcinoma, Am. J. Pathol. 178 (2011) 2866-2878, https://doi.org/10.1016/j. ajpath.2011.02.017.

[72] H. Son, A. Moon, Epithelial-mesenchymal transition and cell invasion, Toxicol. Res. 26 (2010) 245-252, https://doi.org/10.5487/TR.2010.26.4.245.

[73] G. Berx, F. van Roy, Involvement of members of the cadherin superfamily in cancer, Cold Spring Harb. Perspect. Biol. 1 (2009) a003129, , https://doi.org/10.1101/ cshperspect.a003129.

[74] M.W. Klymkowsky, P. Savagner, Epithelial-mesenchymal transition: a cancer researcher's conceptual friend and foe, Am. J. Pathol. 174 (2009) 1588-1593, https://doi.org/10.2353/ajpath.2009.080545.

[75] J. Xu, S. Lamouille, R. Derynck, TGF-beta-induced epithelial to mesenchymal transition, Cell Res. 19 (2009) 156-172, https://doi.org/10.1038/cr.2009.5.

[76] U.G. Lo, C.F. Lee, M.S. Lee, J.T. Hsieh, The role and mechanism of epithelial-toMesenchymal transition in prostate Cancer progression, Int. J. Mol. Sci. 18 (10) (2017) E2079, , https://doi.org/10.3390/ijms18102079.

[77] H. Peinado, D. Olmeda, A. Cano, Snail, Zeb and bHLH factors in tumour progression: an alliance against the epithelial phenotype? Nat. Rev. Cancer 7 (2007) 415-428, https://doi.org/10.1038/nrc2131.

[78] D.S. Micalizzi, S.M. Parabaugh, H.L. Ford, Epithelial-mesenchymal transition in cancer: parallels between normal development and tumor progression, J. Mammary Gland Biol. Neoplasia 15 (2010) 117-134, https://doi.org/10.1007/s10911-0109178-9.

[79] D. Oral, P. Erkekoglu, B. Kocer-Gumusel, M.W. Chao, Epithelial-mesenchymal transition: a special focus on phthalates and Bisphenol A, J. Environ. Pathol. Toxicol. Oncol. 35 (2016) 43-58, https://doi.org/10.1615/ JEnvironPatholToxicolOncol.2016014200.

[80] C.B. Herath, W. Jin, G. Watanabe, K. Arai, A.K. Suzuki, K. Taya, Adverse effects of environmental toxicants, octylphenol and Bisphenol A, on male reproductive functions in pubertal rats, Endocrine 25-2 (2004) 163-172, https://doi.org/10 1385/ENDO:25:2:163.

[81] O. Takahashi, S. Oishi, Testicular toxicity of dietarily or parenterally administered bisphenol A in rats and mice, Food Chem. Toxicol. $41-47$ (2003) 1035-1044, https://doi.org/10.1016/S0278-6915(03)00031-0.

[82] O. Takahashi, S. Oishi, Testicular toxicity of dietary 2,2-bis(4-hydroxyphenyl)propane (bisphenol A) in F344 rats, Arch. Toxicol. 75 (2001) 42-51.

[83] H.M. Lam, S.M. Ho, J. Chen, M. Medvedovic, N.N.C. Tam, Bisphenol A disrupts HNF4 $\alpha$-regulated gene networks linking to prostate preneoplasia and immune disruption in Noble rats, Endocrinology 157 (2016) 207-219, https://doi.org/10. 1210/en.2015-1363.

[84] M. Yang, S.N. Li, K.M. Anjum, L.X. Gui, S.S. Zhu, J. Liu, J.K. Chen, Q.F. Liu, G.D. Ye, W.J. Wang, J.F. Wu, W.Y. Cai, G.B. Sun, Y.J. Liu, R.F. Liu, Z.M. Zhang, B.A. Li, A double-negative feedback loop between Wnt- $\beta$-catenin signaling and HNF4 $\alpha$ regulates epithelial-mesenchymal transition in hepatocellular carcinoma, J. Cell. Sci. 126 (2013) 5692-5703, https://doi.org/10.1242/jcs.135053.

[85] F. Gounari, S. Signoretti, R. Bronson, L. Klein, W.R. Sellers, J. Kum, A. Siermann, M.M. Taketo, B.H. von, K. Khazaie, Stabilization of betacatenin induces lesions reminiscent of prostatic intraepithelial neoplasia, but terminal squamous transdifferentiation of other secretory epithelia, Oncogene 21 (2002) 4099-4107, https:// doi.org/10.1038/sj.onc.1205562.

[86] F. Sun, H.G. Chen, W. Li, X. Yang, X. Wang, R. Jiang, Z. Guo, H. Chen, J. Huang, A.D. Borowsky, Y. Qiu, Androgen receptor splice variant AR3 promotes prostate cancer via modulating expression of autocrine/ paracrine factors, J. Biol. Chem. 289 (2014) 1529-1539, https://doi.org/10.1074/jbc.M113.492140.

[87] C. Kudo-Saito, H. Shirako, T.Takeuchi Y. Kawakami, Cancer metastasis is accelerated through immunosuppression during Snail-induced EMT of cancer cells, Cancer Cell 15 (2009) 195-206, https://doi.org/10.1016/j.ccr.2009.01.023.

[88] J.J. Christiansen, A.K. Rajasekaran, Reassessing epithelial to mesenchymal transition as a prerequisite for carcinoma invasion and metastasis, Cancer Res. 66 (2006) 8319-8326, https://doi.org/10.1158/0008-5472.CAN-06-0410.

[89] W. Yong, C. Jiao, W. Jianhui, Z. Yan, P. Qi, W. Xiu, S. Zuyue, Z. Yunhui, Mono-2ethyhexyl phthalate advancing the progression of prostate cancer through activating the hedgehog pathway in LNCaP cells, Toxicol. In Vitro 32 (2016) 86-91, https://doi.org/10.1016/j.tiv.2015.12.012.

[90] A. Abidi, Hedgehog signaling pathway: A novel target for cancer therapy: Vismodegib, a promising therapeutic option in treatment of basal cell carcinomas, Indian J. Pharmacol. 46-1 (2014) 3-12, https://doi.org/10.4103/0253-7613. 124884.

[91] A. Potti, I. Sehgal, Exposure to pesticides increases levels of uPA and uPARin premalignant human prostate cells, Environ. Toxicol. Pharmacol. 19 (2005) 215-219, https://doi.org/10.1016/j.etap.2004.04.010.

[92] Y. Xu, E.J. Tokar, R.J. Person, R.G. Orihuela, N.N.O. Ngalame, M.P. Waalkes, Recruitment of normal stem cells to an oncogenic phenotype by noncontiguous carcinogen-transformed epithelia depends on the transforming carcinogen, Environ. Health Perspect. 121 (2013) 944-950, https://doi.org/10.1289/ehp.1306714.

[93] IARC (International Agency for Research on Cancer), Cadmium and Cadmium Compounds. IARC Monogr Eval Carcinog Risk Hum 100C, Available: (2012), pp 121-145 (Accessed 9 July 2013), http://monographs.iarc.fr/ENG/Monographs/ vol100C/mono100C.pdf.

[94] A. Zhang, M. Hitomi, N. Bar-Shain, Z. Dalimov, L. Ellis, K.K. Velpula, G.C. Fraizer, R.G. Gourdie, J.D. Lathia, Connexin 43 expression is associated with increased malignancy in prostate cancer cell lines and functions to promote migration, Oncotarget 6-13 (2015) 11640-11651, https://doi.org/10.18632/oncotarget.3449.

[95] Q. Liu, X. Ji, Z. Ge, H. Diao, X. Chang, L. Wang, Q. Wu, Role of connexin 43 in cadmium-induced proliferation of human prostate epithelial cells, J. Appl. Toxicol. 37 (2017) 933-942, https://doi.org/10.1002/jat.3441.

[96] S.M. Ho, A. Cheong, M.A. Adgent, J. Veevers, A.A. Suen, N.N.C. Tam, Y.K. Leung, W.N. Jefferson, C.J. Williams, Environmental factors, epigenetics, and developmental origin of reproductive disorders, Reprod.Toxicol. 68 (2017) 85-104, https://doi.org/10.1016/j.reprotox.

[97] C.P. Wild, Complementing the genome with an "exposome": the outstanding challenge of environmental exposure measurement in molecular epidemiology, Cancer Epidemiol. Biomarkers Prev. 14 (2005) 1847-1850, https://doi.org/10.1158/10559965.EPI-05-0456.

[98] G.W. Miiler, D.P. Jones, The nature of the nurture: refining the definition of the exposome, Toxicol. Sci. 137 (2014) 1-2, https://doi.org/10.1093/toxsci/kft251.

[99] G.S. Prins, O. Putz, Molecular signaling pathways that regulate prostate gland development, Differentiation 76 (2008) 641-659, https://doi.org/10.1111/j.14320436.2008.00277.x. 